\title{
GENDER AND PREDICTING INTENTIONS AMONG MALAYSIAN TEACHERS
}

\author{
Mohamad Ibrani Shahrimin Adam Assim ${ }^{1 *}$, Salina Janis ${ }^{2}$, Yasmin Yaccob ${ }^{3}$, Nurul Hidayu Mat Jusoh ${ }^{4}$ \\ ${ }^{1 * 3,4}$ Universiti Putra Malaysia Bintulu Campus, Sarawak, Malaysia; ${ }^{2}$ SMK Baru, Bintulu, Sarawak, Malaysia. \\ Email: 1*ibrani@upm.edu.my, ${ }^{2}$ salina_janis@gmail.com, ${ }^{3}$ yasmin_y@upm.edu.my, ${ }^{4}$ nurulhidayu@upm.edu.my
}

Article History: Received on $24^{\text {th }}$ July 2020, Revised on $26^{\text {th }}$ August 2020, Published on $17^{\text {th }}$ September 2020

\begin{abstract}
Purpose of the study: This study examined the predictors of intention in career development, specifically the intention of applying for promotion among Malaysian excellent teacher candidates.

Methodology: The premise of the theoretical analyses in this study was based on the Theory of Planned Behavior. The correlational study design was employed to determine the relationship among the variables that ascertain any prediction towards the intention to apply for promotion. 500 respondents were sampled and consist of male (226) and female (274) teachers who are qualified to apply for promotion. Confirmatory Factor Analyses (CFA) was performed to test and validate the measurement model.
\end{abstract}

Main Findings: This study had ascertained that gender does moderate relationships among the study's independent variables and the dependent variable. The result also indicates that the theory of planned behavior is applicable in predicting intention to apply for promotion. For teachers in Malaysia, the intention to apply for promotion will increase if the expectation of others towards applying for promotion also positively increase.

Applications of this study: Gender-related specific assessment can be applied within the teachers' performance appraisal system, particularly for the evaluation on 'Guru Cemerlang' or Excellent Teacher Award by the Ministry of Education in Malaysia.

Novelty/Originality of this study: There is a scarcity of recent studies on the intention of Malaysian teachers to apply for promotion. By using the novel approach of Theory of Planned Behavior and the combination of structural equation modeling analyses, gender was found to moderate the relationship between the expectation of others and their intention to apply for promotion.

Keywords: Intention, Malaysian Teachers, Planned Behavior, Gender, Promotion, Confirmatory Factor Analysis.

\section{INTRODUCTION}

In the year 2005, Malaysian teachers were introduced to the 'Excellence Teacher' (ET) promotion path away as one of the alternative paths to the promotion without having transferred to a management position or post. The objective of the ET Award is to motivate and inspire Malaysian teachers towards enhancing the quality of teaching and learning processes. By the year of 2006, the quota for ET positions are 9,374, and the numbers had increased to 14,327, as per reported by the Promotion Board of Education on the $26^{\text {th }}$ of March 2009 (Ministry of Education, 2016).

The study on the assessment approaches on the 'Excellence Teacher'(ET) candidate conducted in Malaysia is still a new phenomenon. Apart from being a confidential and highly undisclosed matter, any study on ET may pose a viably significant contribution towards the corpus of knowledge in career advancement within the Malaysian education system. The current study examined the role of gender pertaining to the performance appraisal system in influencing the behavioral intentions of teachers in applying for promotional opportunities offered by the ministry. In addition, the hypothesized influence of the teacher's own self-efficacy towards promotion intention was also.

In determining a teacher's intention to apply for promotion, this study applied the Theory of Planned Behavior to investigate between the independent and dependent variables. The theory of planned behavior has been used extensively by numerous researchers around the world in various fields, particularly on the most frequently hypothesized phenomena of how intention can or may predict behavior. When an individual behavior intention is said to be high it will be likely to perform the behavior if complied with the general requirements of the theory of planned behavior that are greater the attitude, subjective norm, and perceived behavioral control.

Hoque et al. (2012) from the discussions and interviews with excellent teachers and those who are eligible to apply for excellent teacher (ET) positions, believed there are a few factors to be the source that hinder the intention of many teachers who are qualified to apply for the post of excellent teachers. Firstly, it was because excellent teachers cannot return to the previous post as a regular teacher. Secondly, because of job relocation factor that demands them to move to other schools according to the needs of the education ministry. However, these factors were not based on empirical studies with no concrete data available.

The turn of the new century had witnessed a greater sense gender sensitization, as men and women are free to engage in their careers and mutual support career development regardless of gender aspects and it also showed that women were actively involved in career development (UNESCO, 2015; UNESCO, 2016). Thus, in applying these aspects from the role congruity framework, men and women are guided by the opportunity structure according to gender role in achieving 
the vision and goals of individuals (Chizema et al., 2015; McIlveen \& Perera, 2016; Dicke et al., 2019; Evans \& Diekman, 2009). Furthermore, an increasing body of literature suggests that traditional gender belief influence differences in term of career matter (Kwak (2018); Javed and Khan (2018); Dicke, 2019; Evans \& Diekman (2009); Canova et al, 2020). In 2013, the total number of teachers in primary and secondary schools in Malaysia was about 418,146, and out of $31.7 \%$ are male and the rest are females (Ministry of Education, 2016). In line with this gender-related phenomena, together with the majority of the teachers involved in education are women, this study was conducted to ascertain the gender factor on its role as a moderator within the intention to apply for promotion, as per ascribed within the framework of TPB by La Barbera and Ajzen (2020), Vamvaka (2020), Armitage and Conner (2001) and Ajzen and Schmidt (2020).

\section{LITERATURE REVIEW}

Many studies have applied the theory of planned behavior in predicting behavioral intention and thus predict actual behavior. The theory of planned behavior is an extension of the theory of reasoned action with the efforts made by Ajzen in the process of improving the prediction of behavior and behavioral intentions. In our efforts to further improve the theory of reasoned by Ajzen, he has highlighted the theory of planned behavior in addressing limitations when faced with behavior control by an individual (Ajzen and Schmidt, 2020; Bosnjak et al., 2020; Vamvaka et al., 2020) with personal

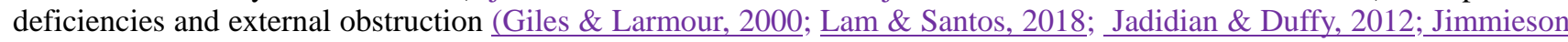
et al., 2008).

In relation to the factor of attitude towards applying for promotion in the study of career development of women by (Giles \& Larmour, 2000), the authors identified six consequences in applying for a promotion that is enhanced job satisfaction, increased salary, enhanced job security, extra responsibility, and increased personal stress or pressure. From the study, they found that employees' attitudes gave a positive reaction towards applying for promotion but unlikely intend to apply for promotion although there is an opportunity for them. Moreover, based on the role congruity theory, women who work in places that are dominated by men will have the potential to suffer from stress at work (Ferguson, 2018; Eagly \& Karau, 2002; Shirom et al., 2008). However, the teaching profession has been known as a profession that was dominated worldwide by females (Giles \& Larmour, 2000); UNESCO, 2015; UNESCO, 2016).

Another factor employed in the current study is the subjective norm. In this paper, the subjective norm refers to social environment pressure that could influence the behavior of an individual (Ajzen \& Schmidt, 2020). The variable of expectation of others towards applying for promotion represents the subjective norm in the framework of the study. From career development aspects such as promotion, they are four referents that include the expectation from a supervisor, colleagues, close friends, and family (Giles \& Larmour, 2000). The individual believed towards those social environment expectations from others around them, influence them to act certain behavior such as applying for promotion from a career development point of view. Social environment pressure does have an important role in convincing a certain behavior or intention to be executed by the individual. Moreover, it has been postulated that gender norms and socialization are among the few environmental factors in a society that greatly influences the choice of individual goals (Evans \& Diekman, 2009). Furthermore, Moreau (2020), Evans and Diekman (2009), and Motulsky (2010) extend the arguments viewing a career change through the social context. Motulsky (2010) categorically emphasizes that career change will combine the ideas of culture and gender on careers, success and achievement, security, and change, in which women may face with inequality within cultural expectations. Thus, women have sacrificed career opportunities such as promotion success due to the family and this factor affects the development of their careers because women often seek a balance between work and career (Shahbaz et al., 2020; Dolan et al., 2011).

Perceived behavior control refers to people's perception of the ease or difficulty of performing the behavior of interest (La Barbera \& Ajzen, 2020). Ajzen and Schmidt (2020) examined and found that Atkinson's theory of achievement motivation is almost similar to the proposed concept of perceived behavioral control. Controllability is also being said as one of two distinct comprised of perceived behavioral control (La Barbera and Ajzen, 2020). It refers to perceived control towards environmental factors and external resources. Various studies were conducted to highlight the importance of justice and procedural fairness of a performance appraisal system such as studies by Pooyan \& Eberhardt (1990) and Oplatka \& Tamir (2009), and more recent research by La Barbera (2020); Raja (2016) and Lam and Santos (2018). These studies had provided some evidence of an indirect relationship between financial measures and organizational commitment and mediated by fairness in performance evaluation procedure and job satisfaction. The current study explored the compatibility of the selected variable from career development indicator specifically the performance appraisal system as a control belief factor in the theory of planned behavior that may affect the intention to apply for promotion. Sinha and Israel (2018) and Pooyan and Eberhardt (1990) emphasize that when supervisors treat their employees equally regardless of gender, the same perception regarding the performance appraisal system will be similarly applied. Geddes \& Konrad (2003) furthers the argument by referring to the result of their study which shows a positive beta weight which indicated that female workers react positively compared to male workers toward a performance appraisal system.

Furthermore, Ajzen and Schmidt (2020) also emphasized on perceived behavioral control is more compatible with selfefficacy as proposed by (La Barbera and Ajzen, 2020). Motives of individual behavior can be influenced by the selfefficacy belief, as well as its impact on the development and subsequent patterns of thought and emotional reaction. The constructs of self-efficacy belief or perceived behavior control in the theory of planned behavior described within the 
general framework of the relationships between beliefs, attitudes, intentions, and behavior. In the study of an extended theory of planned behavior in testing psychological variables mediate sex differences in alcohol consumption by Zimmermann \& Sieverding (2010) the construct of self-efficacy was applied as one of the variables as the concept of perceived behavioral control related to the concept of self-efficacy by Tolentino, et al., (2019). La Barbera and Ajzen $\underline{(2020)}$ emphasized that controllability reflects individual perceived control towards external resources while self-efficacy individual perceived control over internal resources. To be more precise in predicting intention behavior within the career development field, a study by Kwak (2018) incorporating the construct of career decision making self-efficacy in the theory of planned behavior. Literature had consistently identified the factors that cause women to decide not to apply for promotion, which includes lack of aspiration, less conscious about the system of promotion, no confidence, socialization based on gender, fear of failure, and no desire to compete Sulaiman Al Shabibi \& Silvennoinen (2018), Ansari et al. (2016); Oplatka \& Tamir, 2009; Coffey \& Delemont 2000; Bozionelos \& Bennet, 1999).

In line with the worldwide gender-related phenomena, together with the majority of the teachers involved in education are women, the current study examined and investigated gender influences as a moderating effect in predicting the intention to apply for promotion among the excellent teachers' candidate.

\section{METHODOLOGY}

A total of 500 respondents were sampled via a two-stage random cluster sampling method and consists of male (226) and female (274) teachers who are qualified to apply for promotion as per determined by the requirement set by the Malaysian Education Board of Inspectorate. This study employed a correlational study to determine the relationship between the variables. In addition, this study attempted to gauge potential predictors toward intention to apply for promotion with, the application of the theory of planned behavior as the major measurable constructs. Thus, sub-factors and items for the instrument were based and identified by adapting the framework of planned behavior of Ajzen and Schmidt (2020) and Vamvaka et al. (2020). The variables selected in this study were intended to provide a deeper understanding of career development. By adding gender as moderator, this study postulated the role of gender in the relationship between the measured independent and dependent variables. Two hypotheses were constructed and there were as follows: (i) gender will moderate the relationship between teachers' self-efficacy in applying for promotion and their intention to apply for promotion, and (ii) the positive relationship between teachers' belief towards the performance appraisal system for promotion application and their intention to apply for promotion will be moderated by gender. Participants of the survey conducted in the current study involved teachers who are qualified to apply for the excellent teacher (ET) position, as per determined by the requirement set by the Malaysian Education Board of Inspectorate.

To reduce bias in the sample population an attempt was made to utilize teachers from both genders who work in different areas of subject teachings with different educational backgrounds, promotion experiences, and total years of work experience in their current school. The tools for the data collection utilized a method by using the self-assessment questionnaire. The questions were translated from the English Language to Malay Language and modified to suit for teachers to answer. Constructing of items in the questionnaire was based on the study by Giles \& Larmour, (2000), Kwak (2018), and Javed and Khan (2018). A dichotomous variable was used to Giles assess gender, 0 represents male and 1 represents female. A total of 14 items were used in the study and modified to suit for sampled teachers. All items were measured using 7-point Likert-scales ranging from disagree to most agree. The items were altered so that it is suitable to be answered by the teacher that had the potential in applying for an excellent teacher position.

In this study, confirmatory factor analysis (CFA) was used as a primary examination of the instrument. Through confirmatory factor analysis, this study may have attempted to extrapolate the findings of examining the construct validity of the sampled instrument items. Hence, for this purpose, SPSS and AMOS programs were used extensively to analyze the psychometric data gathered. Moreover, a series of reliability tests were conducted, which may require the comparing process of the Cronbach $\alpha$ results from data analysis to $\alpha$ value of 0.7 . As indicated by statistical viabilities, if the result is greater than 0.7 it is indicated with high reliability, and conversely, if the result is less than 0.3 it indicates low reliability. Particularly, confirmatory factor analysis (CFA) was carried out to determine the degree of model fit, the explained variances and standardized residual for the measurement variables, and the adequacy of the factor loadings. "specifically, and item was assigned to a factor when its loading was at least twice its standard error" (Landis et al., 2000). According to the results of CFA for each latent variable, items that they had low factor loading (at least .50), were dropped (Guo et al., 2019).

The main purpose of this study is to investigate the moderator effect of gender towards the relationship between independent variables and dependent variables. To achieve this objective, a multigroup analysis was conducted to investigate the relationship between predictors variables that were Attitude Towards Applying for Promotion (ATAP), Expectation of Other Towards Applying for Promotion (EOTAP), Career Decision Making Self-Efficacy (CDMSE), and Belief Towards Performance Appraisal System (BTPAS) towards Intention Towards Applying for Promotion (ITAP). Multigroup modeling for males and females for measurement model and multigroup path analysis was conducted. The current study also compared the results between the structured model of female and male to determine whether gender does or does not moderate the relationship. The result of the standardized regression weight by both genders was determined and described the moderator effect and strength of the relationship between the variables of the study. 


\section{RESULTS AND DISCUSSION}

\section{A. Measurement Model}

The purpose of the evaluation of the measurement model in this study was to examine the measurement properties of the observed variables. The result in the measurement model 1 had included all items in the study. The results of Confirmatory Factor Analyses (CFA) for measurement model 1 revealed a measurable fit with factor loading ranging from .24 to .98, all construct reliability above .70, and indices of GFI, CFI, NFI, and TLI ranging from .528 - .577 as shown in Tables 1-3.

Table 1: Degree of Freedom and Chi-Square Statistics for Goodness of Fit (Measurement Model 1)

\begin{tabular}{llllll}
\hline Model & NPAR & CMIN & DF & P & CMIN/DF \\
\hline Unconstrained & 96 & 9952.366 & 850 & .000 & 11.709 \\
\hline Saturated model & 946 & .000 & 0 & & \\
\hline Independence model & 43 & 22400.956 & 903 & .000 & 24.807 \\
\hline
\end{tabular}

Source: Data processed

Table 2: Baseline Comparisons (Measurement Model 1)

\begin{tabular}{llllll}
\hline Model & $\begin{array}{l}\text { NFI } \\
\text { Delta1 }\end{array}$ & $\begin{array}{l}\text { RFI } \\
\text { rho1 }\end{array}$ & $\begin{array}{l}\text { IFI } \\
\text { Delta2 }\end{array}$ & $\begin{array}{l}\text { TLI } \\
\text { rho2 }\end{array}$ & CFI \\
\hline Unconstrained & .556 & .528 & .578 & .550 & .577 \\
\hline Saturated model & 1.000 & & 1.000 & & 1.000 \\
\hline Independence model & .000 & .000 & .000 & .000 & .000 \\
\hline
\end{tabular}

Source: Data processed

Table 3: RMSEA (Measurement Model 1)

\begin{tabular}{lllll}
\hline Model & RMSEA & LO 90 & HI 90 & PCLOSE \\
\hline Unconstrained & .146 & .144 & .149 & .000 \\
\hline Independence model & .218 & .216 & .221 & .000 \\
\hline
\end{tabular}

Source: Data processed

Table 1 above shows that there are 96 parameters to be estimated with 850 (946-96) degree of freedom and yielded a significant chi-square value, $\chi^{2}$ value of 9952.366 . Table 2 shows the baseline comparisons fit indices of NFI, RFI, IFI, TLI, and CFI are lower than .9 (range between .528 and .578) thus, indicating that the model does not fit the data well. RMSEA values in Table 3 for this model are .146, also a poor fit as suggested by $\underline{\text { Ho (2006). }}$

Table 4: Computation of Degree of Freedom and Chi-Square Statistics for Goodness-of-Fit

\begin{tabular}{llllll}
\hline Model & NPAR & CMIN & DF & P & CMIN/DF \\
\hline Unconstrained & 44 & 599.152 & 109 & .000 & 5.497 \\
\hline
\end{tabular}

Source: Data processed

Table 5: Incremental Fit Indices

\begin{tabular}{lcccccc}
\hline Model & NFI & RFI & IFI & TLI & CFI & RMSEA \\
\hline Unconstrained & .928 & .910 & .940 & .925 & .940 & .095 \\
\hline
\end{tabular}

Source: Data processed

Table 4 above shows that there are 44 parameters to be estimated with 109 (153-44) degrees of freedom and yielded a significant chi-square value, $\chi^{2}$ value of 599.152. Table 5 shown the baseline comparisons fit indices of NFI, RFI, IFI, TLI, and CFI are greater than .9 (range:.910 to .940), thus indicates that the model fits the data well. RMSEA values for this model are .095 that indicates a mediocre fit as suggested by $\underline{\mathrm{Ho}(2006)}$. In this research, we determined to investigate the role of gender as a moderator between the dependent variable and the independent variable. Thus, it is important to test if the factor structured by the measurement model is the same for males and females. We conducted a multigroup analysis for the measurement model to examine if there are any differences in terms of factor structured for males and females in the measurement model.

This study adapted CFI differences to test for measurement invariance with the CFI difference value of below .05 as a guideline. Qureshi and Compeau (2009) suggested that a nonsignificant difference in $\chi^{2}$ and CFI below 0.05 indicates model invariance. In this study, the value of CFI difference between the group invariant and group variant is .015 but $\chi^{2}$ 
value shown a significantly different (Table 6-8).

Table 6: Computation of Degree of Freedom and Chi-Square Statistics for Goodness-of-Fit

\begin{tabular}{lccccc}
\hline Model & NPAR & CMIN & DF & P & CMIN/DF \\
\hline Group Invariant & 71 & 1268.251 & 235 & .000 & 5.397 \\
\hline Group Variant & 88 & 1112.441 & 218 & .000 & 5.103 \\
\hline
\end{tabular}

Source: Data processed

Table 7: Incremental Fit Indices

\begin{tabular}{lccccccc}
\hline Model & NFI & RFI & IFI & TLI & CFI & RMSEA & AIC \\
\hline Group Invariant & .862 & .840 & .884 & .866 & .884 & .094 & 1410.251 \\
\hline Group Variant & .879 & .849 & .900 & .875 & .899 & .091 & 1288.441 \\
\hline
\end{tabular}

Source: Data processed

Table 8: Nested Model Comparison

\begin{tabular}{lccccccc}
\hline Model & DF & CMIN & P & NFI & IFI & RFI & TLI \\
\hline Group Invariant & 17 & 155.810 & .000 & .017 & .017 & .009 & .009 \\
\hline
\end{tabular}

Source: Data processed

The critical ratio test gender differences for the regression weight. From the test, 10 of the pairwise comparisons between males and females (m1-f1, m13-f13, m12-f12, m8-f8, m14-f14,m15-f15,m2-f2,m5-f5,m6-f6,m3-f3) are significant $(> \pm 1.96, \rho<.05)$.

Note for models: Two data set was used in this multigroup analysis. Each consisting of 12 measurement variables. For the group Invariant model, there are 82 parameters to be estimated. This model has 224 (306-82) degrees of freedom with a significant chi-square value, $\chi^{2}=1161.995, \rho<.05$. For the group invariant model, there are 88 parameters to be estimated. This model has 218 (306-88) degrees of freedom with a significant chi-square value, $\chi^{2}=1150.539, \rho<.05$. Summary of the models: Table 9 consisted of chi-square goodness-of-fit statistic, baseline comparisons fit indices, and model comparison statistic for the group invariant and group variant measurement model.

Table 9: Computation of Degree of Freedom and Chi-Square Statistics for Goodness-of-Fit

\begin{tabular}{cccccc}
\hline Model & NPAR & CMIN & \multicolumn{1}{l}{ DF } & P & CMIN/DF \\
\hline Group Invariant & 82 & 1161.995 & 224 & .000 & 5.187 \\
\hline Group Variant & 88 & 1150.539 & 218 & .000 & 5.278 \\
\hline
\end{tabular}

Source: Data processed

Table 10: Incremental Fit Indices

\begin{tabular}{|c|c|c|c|c|c|c|c|}
\hline Model & NFI & RFI & IFI & TLI & CFI & RMSEA & AIC \\
\hline Group Invariant & .884 & .860 & .905 & .884 & .904 & .092 & 1325.995 \\
\hline Group Variant & .886 & .857 & .905 & .881 & .905 & .093 & 1326.539 \\
\hline
\end{tabular}

Source: Data processed

Table 11: Nested Model Comparison

\begin{tabular}{lccccccc}
\hline Model & DF & CMIN & P & NFI & IFI & RFI & TLI \\
\hline Group Invariant & 6 & 11.456 & .075 & .001 & .001 & -.002 & -.003 \\
\hline
\end{tabular}

Source: Data processed

In this study, the result for the chi-square goodness of fit test projected a significant value for both models. The result for the baseline comparison fit indices of NFI, RFI, IFI, TLI, and CFI are close and above 0.9 (range: 0.884-0.905). The RMSEA values for invariant and variant models are 0.092 and 0.093 . These values suggested that both models are mediocre fit. The invariant model, however, is slightly better than the variant model (Table 9). The result of the AIC 
measure was compared for both models. The group invariant model result of 1325.995 was slightly lower than the variant model (1326.539) that indicates the invariant model more parsimonious and better fitting (Table 10).

By comparing both models, the nested model comparisons statistic indicate that the chi-square difference value of 11.456 (1161.995-1150.539) with 6 degrees of freedom (88-82) is not significant at .05 level $(\rho>.05)$. This indicates that both models do not differ significantly in their goodness of fit (Table 11).

Table 12: Regression Weight, Standardized Regression Weights, and Squared Multiple Correlation

\begin{tabular}{cccccccc}
\hline & & & Estimate & S.E. & C.R. & P & $\boldsymbol{\beta}$ \\
\hline ITAP & $<---$ & ATAP & .299 & .823 & 1.023 & .411 & .257 \\
\hline ITAP & $<---$ & EOTAP & .685 & 1.883 & 2.718 & .040 & .589 \\
\hline ITAP & $<---$ & CDMSE & .191 & 1.548 & -.397 & .122 & .164 \\
\hline ITAP & $<---$ & BTPAS & .010 & .080 & 1.597 & .036 & .008 \\
\hline
\end{tabular}

Source: Data processed

\section{Structured Model for Multi-Group}

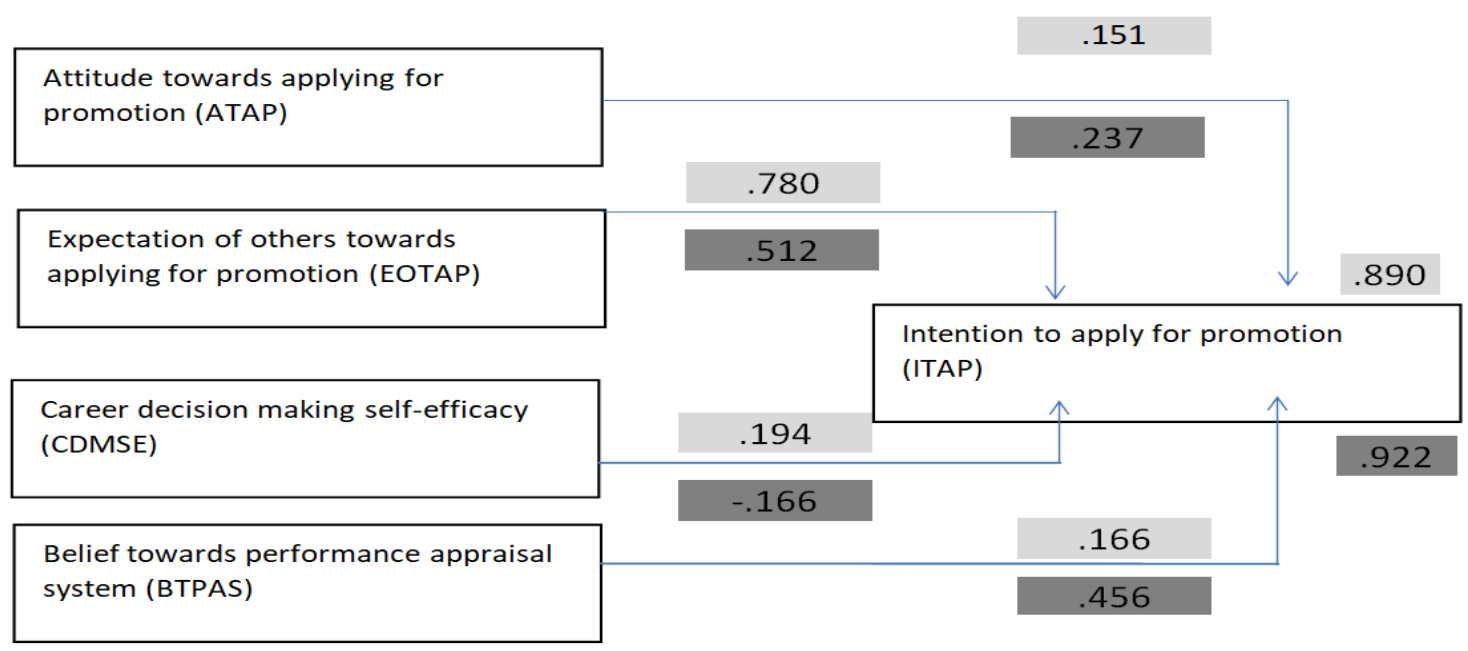

Figure 1: Result of Moderator Test of Gender on Relationship between Predictors and Intention to Apply for Promotion

Male

Female

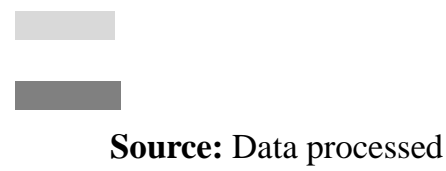

Figure 1 shows that among all four paths that link Intention to Apply for Promotion (ITAP), only Expectation of Others towards Applying for Promotion (EOTAP) and Belief towards Performance Appraisal System (BTPAS) has significant association towards ITAP. The positive direction indicates that the higher the association with EOTAP, the higher the increase of the Intention among Teachers to Apply for Promotion $(\beta=.589)$. BTPAS was found has a little association towards ITAP $(\beta=.008)$. Nonetheless, the other two indicators; ATAP $(\beta=.27)$, CDMSE $(\beta=.164)$ and, were found not significantly supported in teachers Intention to Apply for Promotion. However, based on the result of the squared multiple correlations, the predictors of ATAP, EOTAP, CDMSE, and BTPAS are accounted for .884 or $88.4 \%$ of the variances of ITAP. Thus, this indicates that only .116 or $11.6 \%$ of the correlations were attributed to the unexplained variance for this model. As shown in Figure 1, the findings of the study yielded the result of moderating effects relating to the predictors and intention to apply for promotion with testing the role of gender as the moderator between the independent and dependent variables. Figure 1 represents the standardized estimates of the test and the result of the path coefficient for all the predictors in the study according to the gender of male and female teachers.

The path coefficient result for the variable of attitude towards applying for promotion in predicting intention to apply for promotion shows a nonsignificant result for male .151 versus for female .237 . The expectation of others towards applying for promotion in predicting intention to apply for promotion shows a significant result between both genders. Both females and teachers the result of .780 and .512 indicate a slightly greater association among male teachers compare to female teachers. For predictor of career decision making self-efficacy, the result shows a nonsignificant association by the predictor towards their intention in applying for promotion. With the significant value of a standardized regression weight of .166 for males and .45 for females, it is shown that female teachers have a greater association between the variable of belief towards performance appraisal system and intention to apply for promotion (Table 12.). However, based on the 
result of the squared multiple correlations, the predictors of ATAP, EOTAP, CDMSE, and BTPAS for males' teachers are accounted for .890 or $89 \%$ of the variances of ITAP. Thus, this indicates that only .11 or $11 \%$ of the correlations were attributed to the unexplained variance for this model. While for female teachers the predictors of ATAP, EOTAP, CDMSE, and BTPAS are accounted for .922 or $92.2 \%$ of the variances of ITAP. Thus, this indicates that only .078 or $7.8 \%$ of the correlations were attributed to the unexplained variance for this model.

\section{DISCUSSION}

The theory of Planned Behavior has been applied widely in previous career development research (Giles \& Larmour, 2000). The theory has been proven to be successful in predicting intention and applicable in many aspects of research requirements (Guo et al., 2019). Theory of Planned Behavior is a framework that allows each individual to be distinguished and enables us to interpret the actions of individuals by identifying, measuring, and combining beliefs associated with individual or group, it also that allows us to understand the reasons for their own cause of the behavior of interest Glanz et al. (2015). Canova et al. (2020) argued that only a few studies applied in perceived control by measuring more specific constraints or facilitators of control belief in TPB. This is because most of the research applied direct measures of perceived control.

The current study found that the variable Belief towards Performance Appraisal System (BTPAS) is a predictor of intention to apply for promotion. The moderate relationship of BTPAS and Intention to Apply for Promotion (ITAP) indicate that teachers' belief towards the performance appraisal system that is used in the evaluation for the promotion application does influence the intention of Malaysian teachers to apply for promotion (for example the excellent teachers' post). The positive direction of relationship shows that the intention to apply for promotion might increase when their belief towards the performance appraisal system is increasing. Thus, it is argued that the teacher's belief towards the performance appraisal system can be one of the factors that contribute in motivate most of the qualified teachers for the post of excellent teachers to apply for the position. From the study of Saraih et al. (2015) and Hoque et al. (2012) based on their interviewed information, a few factors were found demotivate qualified teachers for the post of Excellent Teachers that are: 1) the Excellent Teachers were not allowed to return as regular teacher 2) they can be transferred as per requirement from the Ministry of Education. In line with these two factors, no further research was conducted to support the significance of the relationship towards the behavior (Saraih et al., 2015). Hence, the current study included Belief towards Performance Appraisal System (BTPAS) as one of the predictors of intention to apply for promotion, thus indicate that BTPAS is one of the contributors in predicting intention to apply for promotion among teachers in Malaysia, in general.

The present finding has provided strong support that gender does moderate the relationship between independent variables and intention to apply for promotion. Although there was a significant difference in the regression weight value between male and female the value for both genders, males were implied to be more concerned of significant others or the societies' perception towards their career achievement. As asserted by Evans \& Diekman (2009) and Tellhed et al. (2018) career for males are perceived as facilitating improvement in their status goals. In other words, promotion can be seen as a positive achievement and will contribute in enhancing the male teachers' status in society. In another study by Shahbaz et al. (2020) and Dolan et al. (2011), McGinn \& Oh (2017), and (Cabrera et al., 2019) when a comparison is made between women and men, women view the prospect of a career based on balance and security characteristic. The current study found that attitude towards applying for promotion has a nonsignificant correlation with the dependent variable, as the male and female teachers were not affected of consequences in applying for promotion. The result for belief towards the performance appraisal system differs between the female teachers and male teachers. Female teachers were more affected to apply for promotion compared to their male counterparts. Their belief in the performance appraisal system is positively affecting their intention to apply for promotion. In the evaluation process for promotion, the teachers might not feel familiar with the system because of the confidentiality of the instrument used in assessing the candidate for promotion. Less information provided in the process of promotion evaluation might be one of the reasons in hindering teacher's intention to apply for promotion. However, when the teachers are more familiar with the appraisal system it will eventually motivate them to apply for promotion. It can be concluded that the increase of belief towards a performance appraisal system might eventually motivate and increase both female and male teachers' intention to apply for promotion when there is an opportunity.

The findings of this study had shown that the theory of planned behavior is applicable in predicting intention to apply for promotion. With the combination of structural equation modeling processes, this study had compared results between gender. It is concluded that gender does moderate the relationship between the independent and dependent variables of this study.

\section{CONCLUSION}

Over the past years, the Ministry of Education has sought to elevate the teaching profession in Malaysia. The procedures involved in the promotion of the teaching sector was recently upgraded for the continuing improvement purposes. It has been cited in various reports and studies that the time-based system in which promotion to be awarded was shortened from ten years to eight years of qualified services. Consequently, this option will eventually offer the teachers to cut short of the years to qualify for promotion from eight years to a minimum of five years. 
This study had examined the relationship between potential predictors and the variable of intention to apply for promotion among teachers in Malaysia. The moderator effect of gender in the relationship between various variables was explored. Teachers were found to be primarily influenced by two predictors, which are an expectation of others towards applying for promotion, and belief towards applying for promotion. This study also determined that teachers should exert more attention and be more proactive in seeking information for their opportunities in career development. The findings of this study support a large body of literature that consistently suggest that positive career development. It is also suggested that success in career advancement does have their implications on creating satisfaction in performing tasks, and therefore, will eventually contribute to the teaching profession. Malaysian teachers should realize that promotion opportunity was mainly and constantly viewed as channelled for the teachers' own benefit. Teachers are directly implicated as to not rely totally on others' opinions, particularly on their capabilities, and specifically on the qualification to apply for their own promotion.

\section{LIMITATION AND STUDY FORWARD}

This study acknowledged the limitations such as: (i) the determined population that limits to Malaysian teachers and (ii) the sample of only Excellent Teacher Award candidates did not represent the whole population of Malaysian teachers. Notwithstanding the main objective in introducing excellent teachers' position was to enhance the quality of teaching and learning process, some of the major implications of the current study on the policies involved are beneficial to all teaching sectors, particularly in the Malaysian educational system. Nonetheless, more information is indeed required for further researches, particularly regarding the gender and social factors of the current appraisal system.

\section{ACKNOWLEDGEMENT}

This study and report have no financial implications at all it is purely a report done to study the relationship between gender and intention to apply for promotion among Malaysian teachers. The author would like to acknowledge the contributions and suggestions in relation to the development of this article to Professor Dr. Aminah Ahmad for her academic and technical writing suggestions and advice, Dr. Zoharah Omar for her analytical comments and article writing comments, and Associate Professor Dr. Roziah Mohd. Rasdi for her overall comments on the study particularly on the development and critical outcomes of the literature review section.

\section{AUTHORS CONTRIBUTION}

Associate Professor Dr. Mohamad Ibrani Shahrimin Adam Assim had contributed towards the construction of the study's framework, data gathering processes among the Malaysian teachers, and methodological procedures and analytical processes of the study. Salina Janis had contributed extensively towards data collection processes, developing an analytical framework, and conducting SEM analyses and report writing for the study. Dr. Yasmin Yaccob had analysed and modified the draft of this manuscript and involved directly with the data gathering processes and analysing the pilot and actual study data. Dr. Nurul Hidayu Mat Jusoh had contributed significantly in editing the preliminary drafts and commenting on the literature review section and result from analyses. She was also directly involved in the data gathering process and analytical procedures.

\section{REFERENCES}

1. Ajzen, I., \& Schmidt, P. (2020). Changing Behavior Using the Theory of Planned Behavior. The Handbook of Behavior Change, 17-31. https://doi.org/10.1017/9781108677318.002

2. Ansari, N., Moazzam, A., Jabeen, N., \& Salman, Y. (2016). Gender and Perceptions of Organizational Justice: A Study of University of the Punjab. Pakistan Journal of Women's Studies: Alam-e-Niswan, 23(1), $45-63$. https://www.researchgate.net/profile/Amani_Moazzam/publication/313978145_Gender_and_perceptions_of_org anizational_justice A study of the University of the Punjab/links/58b1aca0aca2725b5416dd52/Gender-andperceptions-of-organizational-justice-A-study-of-the-University-of-the-Punjab.pdf

3. Armitage, C. J., \& Conner, M. (2001). Efficacy of the Theory of Planned Behavior: A meta-analytic review. British Journal of Social Psychology, 40, 471 - 499. https://doi.org/10.1348/014466601164939

4. Bosnjak, M., Ajzen, I., \& Schmidt, P. (2020). The Theory of Planned Behavior: Selected Recent Advances and Applications. Europe's Journal of Psychology, 16(3), 352-356. https://doi.org/10.5964/ejop.v16i3.3107

5. Bozionelos, G. \& Bennet, P. (1999). The theory of planned behavior as predictor of exercise: The moderating influence of beliefs and personality variables. Journal of Health Psychology, 4, 517 - 529. https://doi.org/10.1177/135910539900400406

6. Cabrera, G. A., Ann Christine Conde, C. L., \& Angela Ingles, K. S. (2019). Difficulties on Work-Life Balance of Married Career Women: The Case of Generation X. Asia Pacific Journal of Academic Research in Business Administration, 5(1), 16-21. https://www.researchgate.net/publication/339973485_Difficulties_on_WorkLife Balance of Married_Career_Women The Case of Generation X

7. Canova, L., Bobbio, A., \& Manganelli, A. M. (2020). Predicting fruit consumption: A multi-group application of the Theory of Planned Behavior. Appetite, 145, 104490. https://doi.org/10.1016/j.appet.2019.104490

8. Chizema, A., Kamuriwo, D. S., \& Shinozawa, Y. (2015). Women on corporate boards around the world: Triggers and barriers. The Leadership Quarterly, 26(6), 1051-1065. https://doi.org/10.1016/j.leaqua.2015.07.005 
9. Coffey, Amanda \& Delamont, Sara (2000). Feminism and the Classroom Teacher Research, Praxis, and Pedagogy. Routledge/Falmer, New York. https://doi.org/10.1016/j.tate.2005.03.011

10. Dicke, A.-L., Safavian, N., \& Eccles, J. S. (2019). Traditional Gender Role Beliefs and Career Attainment in STEM: A Gendered Story? Frontiers in Psychology, 10, 13-19. https://doi.org/10.3389/fpsyg.2019.01053

11. Dolan, S. L., Bejarano, A., \& Tzafrir, S. (2011). Exploring the moderating effect of gender in the relationship between individuals' aspirations and career success among engineers in Peru. International Journal of Human Resource Management, 22(15), 3146-3167. https://doi.org/10.1080/09585192.2011.560883

12. Eagly, A. H., \& Karau, S. J. (2002). Role congruity theory of prejudice toward female leaders. Psychological Review, 109(3), 573-598. https://doi.org/10.1037/0033-295X.109.3.573

13. Evans, C. D., \& Diekman, A. B. (2009). On motivated role selection: Gender beliefs, distant goals, and career interest. Psychology of Women Quarterly, 33(2), 235-249. https://doi.org/10.1111/j.1471-6402.2009.01493.x

14. Ferguson, T. W. (2017). Female Leadership and Role Congruity within the Clergy: Communal Leaders Experience No Gender Differences Yet Agentic Women Continue to Suffer Backlash. Sex Roles, 78(5-6), 409422. https://doi.org/10.1007/s11199-017-0803-6

15. Fritz, C., \& van Knippenberg, D. (2017). Gender and leadership aspiration: the impact of organizational identification. Leadership \& Organization Development Journal, 38(8), $1018-1037$. https://doi.org/10.1108/LODJ-05-2016-0120

16. Geddes, D., \& Konrad, A. M. (2003). Demographic differences and reactions to performance feedback. Human Relations, 56(12), 1485-1513. https://doi.org/10.1177/00187267035612003

17. Giles, M., \& Larmour, S. (2000). The theory of planned behavior: A conceptual framework to view the career development of women. Journal of Applied Social Psychology, 30(10), 2137-2157. https://doi.org/10.1111/j.1559-1816.2000.tb02429.x

18. Glanz, K., Rimer, B. K., \& Viswanath, K. (2015). Health Behavior: Theory, Research, and Practice (JosseyBass Public Health) (5th ed.). Jossey-Bass.

19. Guo, R., Berkshire, S. D., Fulton, L. V., \& Hermanson, P. M. (2019). Predicting intention to use evidence-based management among U.S. healthcare administrators: Application of the theory of planned behavior and structural equation modeling. International Journal of Healthcare Management, 12(1), $25-32$. https://doi.org/10.1080/20479700.2017.1336856

20. Ho, R. (2006). Handbook of Univariate and Multivariate Data Analysis with IBM SPSS, Second Edition, Florida: Taylor \& Francis CRC Press. https://doi.org/10.1201/b15605

21. Hoque, K. E., Ahmad Zabidi Abdul Razak, \& Zohora, M. F. (2012). ICT Utilization among School Teachers and Principals in Malaysia. International Journal of Academic Research in Progressive Education and Development, 1(4), 17-34. https://core.ac.uk/download/pdf/162012489.pdf

22. Jadidian, A., \& Duffy, R. D. (2012). Work volition, career decision self-efficacy, and academic satisfaction: An examination of mediators and moderators. Journal of Career Assessment, 20(2), 154-165. https://doi.org/10.1177/1069072711420851

23. Javed, R., \& Khan, M. (2018). Development and Standardization of Career Decision Making Self-Efficacy Scale. 5. 569-578.

24. Jimmieson, N. L., Peach, M., \& White, K. M. (2008). Utilizing the theory of planned behavior to inform change management: An investigation of employee intentions to support organizational change. Journal of Applied Behavioral Science, 44(2), 237-262. https://doi.org/10.1177/0021886307312773

25. Kwak, M. (2018). The Causal Relationships among Career Preparation Behavior, Career Uncertainty, Career Decision-making Self-Efficacy, self-concept clarity and Career Insight in University Students. Journal Of Agricultural Education and Human Resource Development, 50(1), 151-177. https://doi.org/10.23840/agehrd.2018.50.1.151

26. La Barbera, F., \& Ajzen, I. (2020). Control Interactions in the Theory of Planned Behavior: Rethinking the Role of Subjective Norm. Europe's Journal of Psychology, 16(3), 401-417. https://doi.org/10.5964/ejop.v16i3.2056

27. Lam, M., \& Santos, A. (2018). The Impact of a College Career Intervention Program on Career Decision SelfEfficacy, Career Indecision, and Decision-Making Difficulties. Journal of Career Assessment, 26(3), 425444. https://doi.org/10.1177/1069072717714539

28. Landis, R. S., Beal, D. J., \& Tesluk, P. E. (2000). A Comparison of Approaches to Forming Composite Measures in Structural Equation Models. Organizational Research Methods, 3(2), $186-207$. https://doi.org/10.1177/109442810032003

29. McGinn, K. L., \& Oh, E. (2017). Gender, social class, and women's employment. Current Opinion in Psychology, 18, 84-88. https://doi.org/10.1016/j.copsyc.2017.07.012

30. McIlveen, P., \& Perera, H. N. (2016). Career Optimism Mediates the Effect of Personality on Teachers' Career Engagement. Journal of Career Assessment, 24(4), 623-636. https://doi.org/10.1177/1069072715616059

31. Ministry of Education. (2016). Quick Facts 2016: Malaysia Educational Statistics. Quick Facts 2016, Malaysia Educational Statistics, 1-45. https://www.moe.gov.my/en/muat-turun/laporan-dan-statistik/quick-factsmalaysia-education-statistics

32. Moreau, M.-P. (2018). A matter of time? Gender equality in the teaching profession through a cross-national comparative lens. Gender and Education, 32(6), 820-837. https://doi.org/10.1080/09540253.2018.1533918 
33. Motulsky, S. L. (2010). Relational Processes in Career Transition: Extending Theory, Research, and Practice. The Counseling Psychologist, 38(8), 1078-1114. https://doi.org/10.1177/0011000010376415

34. Oplatka, I., \& Tamir, V. (2009). "I don't want to be a school head": Women deputy heads' insightful constructions of career advancement and retention. Educational Management Administration and Leadership, 37(2), 216-238. https://doi.org/10.1177/1741143208100299

35. Pooyan, A., \& Eberhardt, B. J. (1990). Predictors of Performance Appraisal Satisfaction: The Effect of Gender. Asia Pacific Journal of Human Resources, 28(1), 82-89. https://doi.org/10.1177/103841119002800107

36. Qureshi, I., \& Compeau, D. (2009). Assessing between-group differences in information systems research: A comparison of covariance- and component-based SEM. MIS Quarterly: Management Information Systems, 33(1), 197-214. https://doi.org/10.2307/20650285

37. Raja, Bushra Inayat. (2016). Social Factors and Women's Career Advancement to Senior Management Position In Pakistan. Asia Pacific Journal of Contemporary Education and Communication Technology, 2(1), 134 - 145. https://apiar.org.au/wp-content/uploads/2016/03/13_APJCECT_ICTP_BRR740_EDU-134-145.pdf

38. Saraih, U. N., Ali, H., \& Khalid, S. A. (2015). The Development of Teachers' Career in Relationship to OCB and Justice: A Study in Malaysia. Asian Social Science, 11(24), 12-21. https://doi.org/10.5539/ass.v11n24p62

39. Shahbaz, M., Gao, C., Zhai, L., Shahzad, F., \& Arshad, M. R. (2020). Moderating Effects of Gender and Resistance to Change on the Adoption of Big Data Analytics in Healthcare. Complexity, 2020, 1-13. https://doi.org/10.1155/2020/2173765

40. Shirom, A., Gilboa, S. S., Fried, Y., \& Cooper, C. L. (2008). Gender, age and tenure as moderators of workrelated stressors' relationships with job performance: A meta-analysis. Human Relations, 61(10), 1371-1398. https://doi.org/10.1177/0018726708095708

41. Sinha, R., \& Israel, D. (2018). Employees' participation in CSR initiatives and job outcomes - affective commitment, job satisfaction, organisational attractiveness, organisational performance and turnover intention. International Journal of Business and Emerging Markets, $10(2), \quad 177$. https://doi.org/10.1504/IJBEM.2018.091265

42. Sulaiman Al Shabibi, A., \& Silvennoinen, H. (2018). Challenges in Education System Affecting Teacher Professional Development in Oman. Athens Journal of Education, 5(3), 261-282. https://doi.org/10.30958/aje.5$\underline{3-3}$

43. Tellhed, U., Bäckström, M., \& Björklund, F. (2018). The role of ability beliefs and agentic vs. communal career goals in adolescents' first educational choice. What explains the degree of gender-balance? Journal of Vocational Behavior, 104(April 2017), 1-13. https://doi.org/10.1016/j.jvb.2017.09.008

44. Tolentino, L. R., Sibunruang, H., \& Garcia, P. R. J. M. (2019). The Role of Self-Monitoring and Academic Effort in Students' Career Adaptability and Job Search Self-Efficacy. Journal of Career Assessment, 27(4), 726740. https://doi.org/10.1177/1069072718816715

45. UNESCO Institute of Statistics. (2016). http://data.uis.unesco.org

46. Vamvaka, V., Stoforos, C., Palaskas, T., \& Botsaris, C. (2020). Attitude toward entrepreneurship, perceived behavioral control, and entrepreneurial intention: dimensionality, structural relationships, and gender differences. Journal of Innovation and Entrepreneurship, 9(1), 35-42. https://doi.org/10.1186/s13731-020-0112$\underline{0}$

47. Warmerdam, A., Lewis, I., \& Banks, T. (2015). Gen Y recruitment. Education + Training, 57(5), 560-574. https://doi.org/10.1108/ET-12-2013-0133

48. Xin, L., Tang, F., Li, M., \& Zhou, W. (2020). From School to Work: Improving Graduates' Career DecisionMaking Self-Efficacy. Sustainability, 12(3), 804. https://doi.org/10.3390/su12030804

49. Zimmermann, F., \& Sieverding, M. (2010). Do Psychological Variables Mediate Sex Differences in Young Adults' Alcohol Use? Substance Use \& Misuse, 46(4), 552-559. https://doi.org/10.3109/10826084.2010.497179 